\title{
Questão agrária, formação social brasileira e dependência
}

Agrarian question, Brazilian social formation and dependence

\section{Nilson weisheimer ${ }^{*}$ \\ michelle sena Rosa de Araújo** \\ Roberto Leher ${ }^{* * *}$}

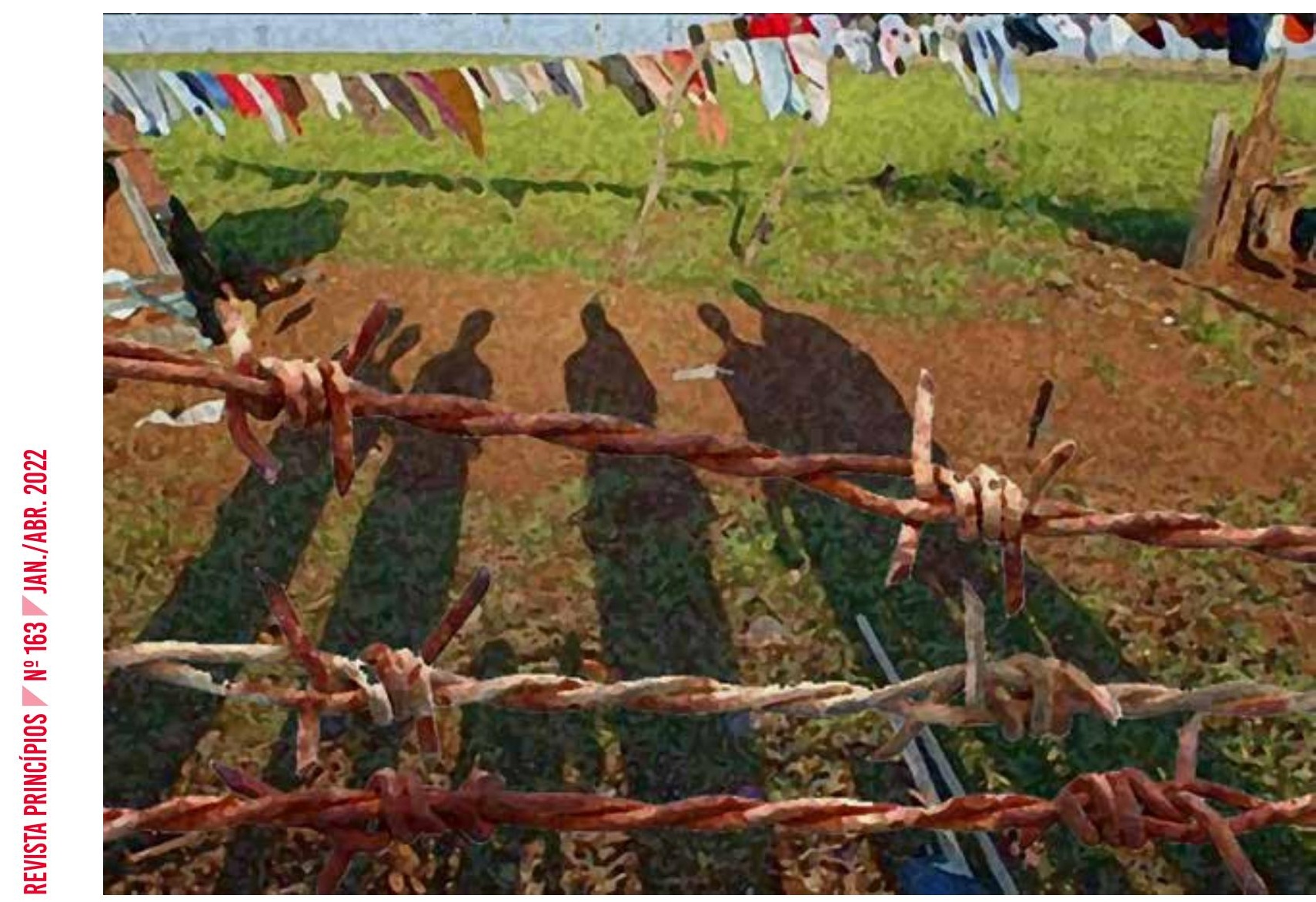




\section{RESUMO}

O artigo objetiva tecer uma análise crítica da questão agrária brasileira como particularidade da nossa formação econômica e social. Recorre ao pensamento social marxista, com destaque para a contribuição teórica de Caio Prado Jr. Propõe que a questão agrária é indissociável do capitalismo dependente. $\mathrm{Na}$ atualidade os latifundiários reforçam sua influência sobre o Estado, através de aparelhos privados de hegemonia, comprometendo a soberania alimentar e o meio ambiente, e acirrando as contradições com agricultores familiares e o proletariado rural em busca por autonomia.

Palavras-chave: Questão agrária. Formação social. Capitalismo dependente.

\section{ABSTRACT}

The article aims to make a critical analysis of the Brazilian agrarian question, as a especificity of Brazilian economic and social formation. It is based on Marxist social thought, emphasizing the theoretical contribution of Caio Prado Jr. It proposes that agrarian question is inseparable from dependent capitalism. Currently, landowners reinforce their influence over the State, through a number of private apparatus of hegemony, putting at risk food sovereignty and environment, and intensifying the contradictions with family farmers and the rural proletariat in search for autonomy.

Keywords: Agrarian question. Social formation. Dependent capitalism. 


\section{INTRODUCC̣̃O}

A compreensão correta e objetiva dos impasses e contradições sociais, políticas e econômicas do Brasil atual não pode deixar de considerar a questão agrária. Longe de configurar agentes econômicos, territórios e enclaves pré-capitalistas, ou um passado que resiste no tempo presente, a questão agrária brasileira é uma expressão da atualidade do capitalismo dependente. A questão agrária resulta da própria dinâmica do desenvolvimento do capitalismo e de sua lei geral de acumulação, em que a produção da riqueza é indissociável da produção social da exploração, das expropriações e da pobreza. Trata-se, portanto, de uma expressão do desenvolvimento desigual, contraditório e combinado das relações capitalistas na agropecuária em suas cadeias produtivas globais de produção de valor.

De fato, a crescente participação do setor de commodities no PIB brasileiro no século XXI denota particularidades do capitalismo dependente que nada têm de anacrônico, pois expressam o modo de produção realmente existente. Em 2020, o chamado "agronegócio" (a rigor, toda cadeia produtiva vinculada ao latifúndio exportador) foi responsável por $26,6 \%$ do PIB brasileiro, percentual que representa um crescimento extraordinário em relação a 2019 (20,5\%) (CEPEA, 202I). Embora acentuadamente dependente de insumos importados e de preços estabelecidos nas principais bolsas de comercialização de commodities do mundo - Korea Futures Exchange, Eurex Deutschland, Chicago Board of Trade (CBOT) —, é um ramo que não se confunde com o "velho latifúndio"; ao contrário, é altamente imbricado com fundos de investimentos, em geral por meio de sociedades anônimas, e que se vale de importante conteúdo tecnológico.

O exame dos principais a parelhos privados de hegemonia (APHs) da burguesia que atua no agronegócio evidencia a complexidade do setor. Os interesses do capital são representados pela Confederação Nacional da Agricultura (CNA) (MENDONÇA, I997), atualmente associada ao poderoso e estruturante Instituto Pensar Agropecuária (IPA), que organiza os interesses gerais do setor. Politicamente, nos grandes APHs do ramo coexistem segmentos que apoiaram os governos do PT e atualmente fazem crítica ao alinhamento de frações ruralistas com o governo Bolsonaro, como Blairo Maggi, a Associação Brasileira das Indústrias de Óleos Vegetais (Abiove), Katia Abreu, Roberto Rodrigues - da Associação Brasileira do Agronegócio (Abag) e representantes dos gigantes empreendimentos. Ao mesmo tempo, no IPA existem frações explicitamente de extrema-direita radicalizada, como o Movimento Brasil Verde e Amarelo, que apoiaram intentos golpistas do governo Bolsonaro, a exemplo da Associação de Desenvolvimento e Amigos da Terra de Carvalhosa (Adaterra) e da Associação dos Produtores de Soja (Aprosoja).

No que tange à agenda ambiental (LAMOSA; LOUREIRO, 20I8), a Abag se afastou da mesa diretora do Instituto Pensar Agropecuária em virtude da tolerância desse APH com a agenda hostil ao meio ambiente, buscando construir uma imagem do agronegócio moderna. Ao fim e ao cabo, todos os referidos APHs pretendem 


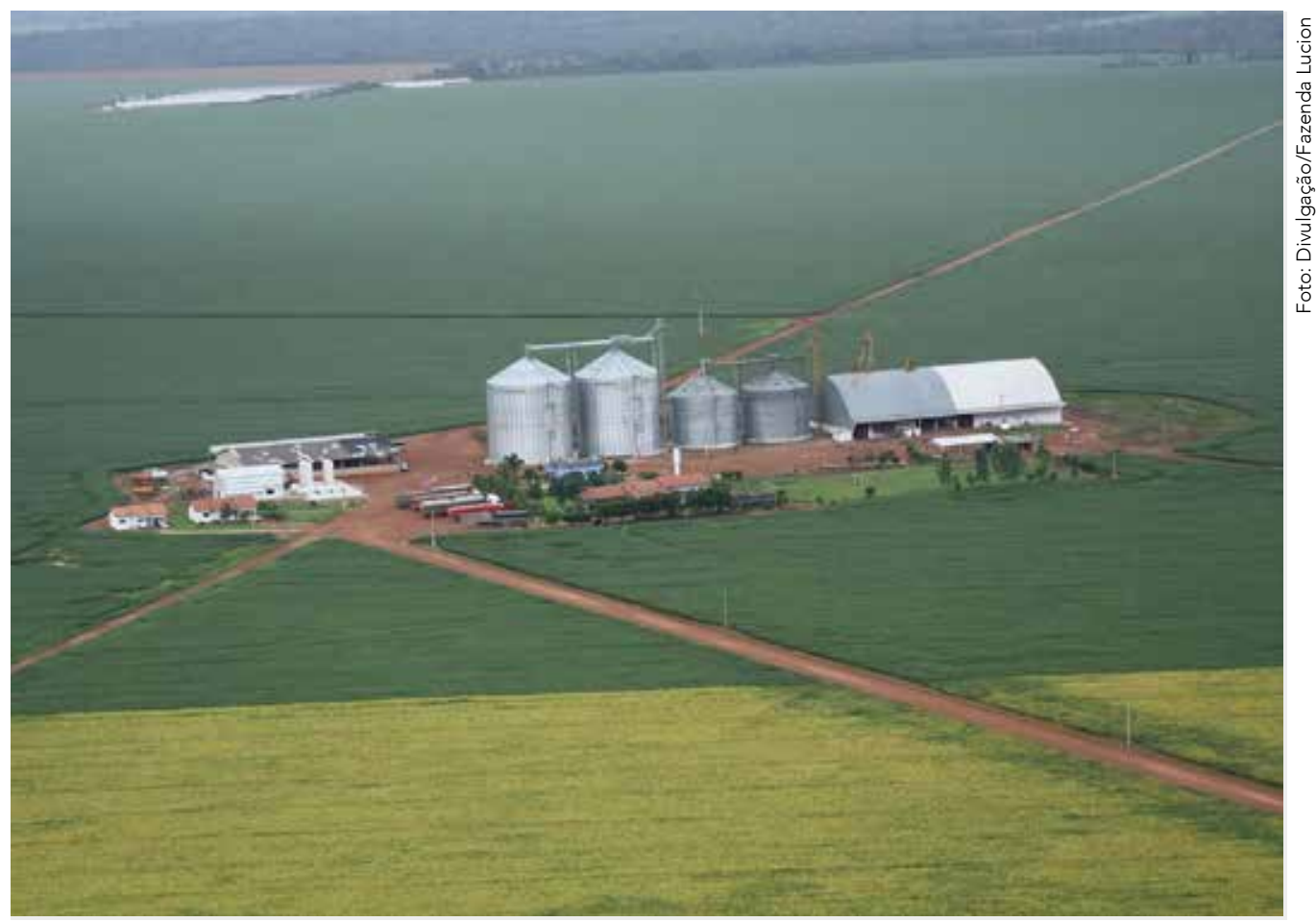

Plantação de soja no município de Vera (MT): latifúndio dedicado à monocultura exportadora

remeter a questão agrária a um passado já superado e que desperta somente ilegítimo interesse ideológico no presente. A lista de programas que buscam apagar os problemas que conformam a questão agrária é longa: "Sou agro", "Agro é tech, agro é pop, agro é tudo"; “Time Agro Brasil”; "Agro: a indústria-riqueza do Brasil”; "De olho no material escolar"; “Todos a uma só voz"...

A bancada ruralista (que tem membros da CNA), impulsionada por setores insatisfeitos com os segmentos industriais do agro, imbuídos do "lava-jatismo", e radicalizada em defesa da anistia do Funrural, foi organizadora do golpe de 2016 e, depois, do governo Bolsonaro, voltando ao leito natural da autocracia burguesa; porém, as contradições entre os APHs do setor não desapareceram. Enquanto a Aprosoja trabalhou em prol do golpe em setembro de 202I, a Abag se manifestou contra o aprofundamento autocrático do governo Bolsonaro (POMPEIA, 2022). Diante do recuo da Fiesp, que chegou a elaborar um texto sobre o tema, mas não logrou consenso em sua publicação, a Abag lançou um manifesto inequivocamente de crítica ao intento golpista (ABAG, 202I), mas sem a adesão da Sociedade Nacional de Agricultura (SNA) e da CNA. De fato, a SNA e a CNA têm em seus quadros forças que apoiaram o intento de ruptura em setembro de 202I.

A pujança econômica, a complexidade das trincheiras dos APHs do setor e sua força política no Legislativo, no Executivo e no Judiciário, assim como as intricadas conexões com a esfera das finanças e, ainda, a importante presença de movimentos de trabalhadores do campo, corroboram a proposição de que a particularidade da 
questão agrária no século XXI requer enfoques críticos sobre o evolucionismo vulgar. Diferentemente de previsões presentes no próprio campo marxista, a exemplo dos estudos de Kautsky, discutidos a seguir, a plena incorporação da agricultura no modo de produção capitalista não obedeceu a um vetor industrializante "clássico", em que a concorrência de grandes capitalistas e a integração ao mercado mundial de commodities engendraria, ao mesmo tempo, um proletariado agrícola e a transformação dos maiores camponeses em integrantes de segmentos subsidiários às corporações (tornando-os membros de empreendimentos ou cooperativas capitalistas). Na perspectiva do marxismo dogmático, transposto para realidades distintas dos casos europeus estudados, sem recontextualizações, o processo do capital paulatinamente destruiria a existência do chamado campesinato, com seus modos familiares de produzir e consumir, seus valores etc.

De fato, o processo de concentração e monopolização da agricultura encolheu o território da agricultura camponesa, atualmente reduzido a 2,3\% da terra agricultável do país (CANAN et al., 202I). Entretanto, as lutas camponesas, entendidas aqui em sentido amplo, envolvendo ribeirinhos, quilombolas, extrativistas e trabalhadores rurais sem-terra, são sumamente relevantes nas lutas sociais no Brasil e na América Latina. Ademais, contraditoriamente, como o grande agronegócio está voltado para o mercado internacional, é a agricultura familiar que assegura cerca de $70 \%$ dos alimentos diversificados que chegam à mesa da população brasileira.

Diferentemente da crença de que a proletarização do campo produziria uma fração da classe trabalhadora com assalariamento clássico, as massas de trabalhadores agrícolas e as populações rurais vivem em situação de pobreza, exploração e expropriação constantes. Pela metodologia atual do IBGE, I5,6\% da população vive em zonas rurais, somando aproximadamente 32 milhões de pessoas. Os indicadores oficiais brasileiros reconheceram que, em 20I9, havia 8 milhões de pessoas em situação de pobreza no meio rural brasileiro. Isto é, pessoas com renda mensal de $\mathrm{R}$ \$ I4O, sendo que quase 50\% desse contingente populacional estava em situação de pobreza extrema, sobrevivendo com renda per capita mensal inferior a R\$ 70. Em 2020, a população em situação de extrema pobreza no Brasil aumentou para I2 milhões de pessoas, enquanto o índice de Gini, que mede a desigualdade de renda, ficou em 0,524, registrando aumento de 3,7\% em relação a 2019 (0,544) (IBGE, 202I). No ano de 2020 cerca de metade da população brasileira (II6,8 milhões de pessoas) convivia com algum nível de segurança alimentar, e $9 \%$ do total da população (I9,I milhões), de forma mais aguda, passava fome.

A situação de pauperização desse imenso contingente populacional é uma das faces mais visíveis do desenvolvimento desigual do capitalismo. No meio rural brasileiro, as expressões mais pujantes estão na concentração fundiária; nos poderosos entraves que obstam a reforma agrária; nos assassinatos de lideranças camponesas; na desigualdade educacional das crianças e juventude do campo em relação às chamadas áreas urbanas, e na persistência de fluxos migratórios de jovens 


\section{A atualidade da questão agrária é intrínseca ao padrão de acumulação capitalista dependente. A estrutura agrária concentrada, beneficiada por generosos repasses do fundo público e subordinada aos centros hegemônicos, a despeito de suas tensões internas, torna-se um obstáculo não só à segurança e à soberania alimentar do conjunto da população brasileira, mas à própria possibilidade de reprodução da força de trabalho no Brasil}

para os centros urbanos, acentuando a queda demográfica relativa. Diferentemente do que é apregoado pela publicidade e pelas ações educativas de determinadas frações burguesas, o multifatorial segmento do agronegócio não é cindido entre um setor moderno e um vasto segmento arcaico, pois existe uma imbricação complexa entre arcaico e moderno, entre defensores de uma economia de baixo carbono e negacionistas climáticos, e assim por diante, na manutenção da estrutura fundiária concentrada em poucas mãos e ancorada em circuitos mundiais da economia que acentuam a crise da soberania e da segurança alimentar.

Nosso argumento central é o de que a atualidade da questão agrária é intrínseca ao padrão de acumulação capitalista dependente. A estrutura agrária concentrada, beneficiada por generosos repasses do fundo público e subordinada aos centros hegemônicos, a despeito de suas tensões internas, torna-se um obstáculo não só à segurança e à soberania alimentar do conjunto da população brasileira, mas à própria possibilidade de reprodução da força de trabalho no Brasil. Isso se evidencia pelos mais de 20 milhões de pessoas que passam fome no país e pela inflação dos gêneros alimentares cotidianos, achatando ainda mais a remuneração dos trabalhadores.

\section{DISCUTIR A QUESTÃO AGRÁRIA É QUESTIONAR O CAPITALISMO DE HOJE}

Nos termos do presente estudo, a questão agrária é uma forma de questionamento do capitalismo hodierno. Em O Capital, Marx nos mostra que no capitalismo: a) todo produto social (e não apenas uma fração excedente dele) toma a forma de mercadoria; b) a própria força de trabalho é uma mercadoria; c) o capital, 
que é uma relação social, cristaliza-se em meios de produção que são também mercadorias. Esse processo possibilita a extração da mais-valia como apropriação privada do valor gerado pelo trabalho social e potencializa a circulação do capital em base ampliada. Marx define ainda que o capitalismo não é simplesmente a produção de mercadorias, mas, precisamente, assinala o fato de que: "I) As mercadorias são produtos do capital; 2) a produção capitalista é a produção de mais-valia; 3) é produção e reprodução do conjunto da relação, e é através disso que esse processo imediato de produção se caracteriza como especialmente capitalista" (MARX, 2004, p. 37).

Destarte, o conceito de formação social refere-se ao conjunto da sociedade, a qual possui uma dupla dimensão imbricada e indissociável: a da infraestrutura e a da superestrutura. Para Weisheimer (2008), uma formação social corresponde a uma totalidade social que guarda, em seu interior, forças produtivas de distintos níveis de desenvolvimento tecnológico, relações sociais de produção diversas e diferentes processos de trabalho, conformando o desenvolvimento desigual do capitalismo.

Nessa formação social haverá uma relação social predominante. Tomemos o caso do Brasil, que é um país continental e com grandes diversidades regionais, culturais e econômicas. Nele há atividades industriais altamente desenvolvidas e integradas ao mercado mundial, atividades financeiras e especulativas e, ao mesmo tempo, relações de trabalho extremamente precárias, informais e mesmo análogas à escravidão. No âmbito da agricultura, coexistem a produção familiar e a produção capitalista com diferentes graus de integração com o mercado mundial de commodities. Essas complexas relações de produção caracterizam a formação social brasileira como capitalista, em sua particularidade dependente.

A estrutura fundiária concentrada está na raiz de desigualdades socioeconômicas alarmantes. Isso, em um país capitalista dependente, desprovido de um projeto autopropelido de nação, tem como desfecho uma sociedade profundamente desigual. Seguindo a linha do raciocínio de Sampaio Jr., em diálogo com a obra de Caio Prado Jr. apresentada com mais detalhes adiante, o próprio "subdesenvolvimento" é uma formação social sui generis, cuja característica distintiva é a existência de relações de produção que impedem a consolidação de uma economia que tenha "existência autônoma" e "força própria". O "subdesenvolvimento" está associado à incapacidade de nações emergentes em "romperem os nexos de dependência herdados da colonização e integrarem, em condições de relativa igualdade, o conjunto de sua população no mercado de trabalho" (SAMPAIO JR., I997, p. II4). Complementarmente, Sampaio Jr. (20I2) aponta a persistente concentração fundiária como um dos principais obstáculos ao desenvolvimento do Brasil enquanto nação. Assim, a existência do latifúndio cumpre um papel determinante no processo de estratificação social no Brasil, na reprodução das estruturas econômicas, sociais, políticas e culturais desiguais e que incidirão sobre o agravamento da pobreza, tanto no meio urbano quanto no rural. 


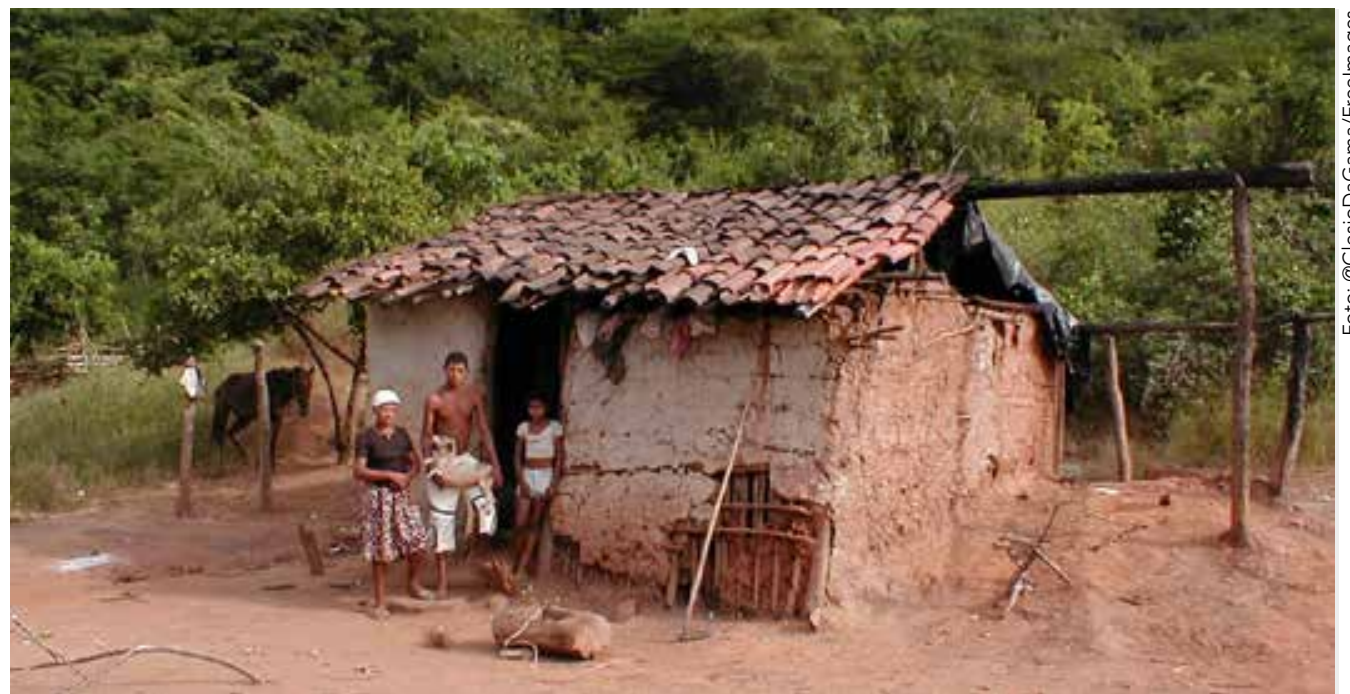

Segundo os indicadores oficiais, em 2019 havia 8 milhões de pessoas em situação de pobreza no meio rural brasileiro

Sampaio Jr. (20I2) reforça o entendimento de que a economia colonial - baseada em latifúndios voltados para a exportação - impôs um padrão de expropriações e de exploração atualizado pelos fundamentos do capitalismo dependente. As diferentes frações da burguesia brasileira, dependentes do capital externo e a ele associadas, constituíram-se em um bloco de poder que tende a bloquear quaisquer mudanças institucionais que venham comprometer seu monopólio da terra e o domínio sobre o conjunto da sociedade, impedindo assim avanços na reforma agrária. Como sócios da exploração colonial de outrora e imperialista atual, asseguram sua sobrevivência promovendo formas de exploração das forças produtivas e manipulando as condições socioambientais internas do país. O grande (e sobretudo o gigante) agronegócio está entranhado no topo do bloco no poder e, por isso, ocupa o centro do poder do Estado nacional, fazendo deste um instrumento da condução de políticas ultraconservadoras, predominantemente antinacionais e antidemocráticas.

A concentração fundiária e as grandes empresas agropecuárias referidas por Caio Prado Jr. (1987) e Sampaio Jr. (2012) têm como marca a manutenção de grande contingente de exército industrial de reserva, repercutindo nos trabalhadores agrícolas e não agrícolas. Em decorrência disso, no contexto brasileiro se reproduz a tendência estrutural de superexploração dos trabalhos na agricultura, devido às assimetrias das condições impostas pela correlação de forças entre capital e trabalho.

Sampaio Jr. (2012) destacou que o principal nexo entre a questão agrária e a problemática da formação social brasileira contemporânea repousa sobre os efeitos negativos do desemprego estrutural e da extrema concentração de renda, bem como das condições de reprodução da força de trabalho no campo. Sob a perspectiva da economia política se observa uma dupla articulação que bloqueia a possibilidade de um desenvolvimento capitalista autodeterminado do Brasil. Por se submeter esse processo de acumulação à violência de um desenvolvimento desigual 
Os impérios

\section{alimentares são}

a expressão das

lutas de classes

e o resultado

da globalização

neoliberal na

agricultura. Ou

seja, são o atual

modo capitalista

de fazer agricultura e combinado (SAMPAIO JR., 20I2), subordina-

se a importância relativa da economia brasileira no âmbito do sistema capitalista mundializado, tornando-a vulnerável aos interesses do grande capital internacional. Já sob a perspectiva da sociologia política, tratase de uma dupla articulação condicionada pelo regime de classes baseado na desigualdade social estruturada de modo a monopolizar o poder político na burguesia nativa, sócia menor da espoliação imperialista.

Essa tendência se fortaleceu na etapa atual do imperialismo, chamada por Chesnais (1996) de "mundialização do capital", que compreende a busca incessante por parte do capital de se libertar das amarras dos direitos sociais e trabalhistas objetivando sua valorização constante. Como efeito, o capital presente nos circuitos agrários também se mundializou. Nesse contexto, as políticas de ajuste estrutural aplicadas, em intensidades diferentes, nos países latino-americanos a partir do marco do neoliberalismo aprofundaram a dependência econômica desses países. Nesse novo regime de acumulação, conforme destaca o geógrafo Ariovaldo de Oliveira, "sob o capitalismo monopolista mundializado, a agricultura passou a estruturar-se sobre uma tríade: a produção de commodities, as bolsas de mercadorias e de futuro[s] e a formação das empresas monopolistas mundiais" (OLIVEIRA, 2015, p. 240).

Essas empresas da agricultura estão cada vez mais vinculadas ao capital financeiro e se constituem em empresas monopolistas mundiais. Segundo Oliveira (2015), esses monopólios se articulam através de dois processos de monopolização no comando da produção agropecuária e florestal mundial: a "territorialização dos monopólios" e a "monopolização do território". Esse autor define assim ambos os processos:

$\mathrm{Na}$ agricultura capitalista mundializada, a territorialização dos monopólios ocorre através do controle da propriedade privada da terra, do processo produtivo no campo e do processamento industrial da produção agropecuária e florestal. Isso quer dizer que o proprietário da terra, o proprietário do capital agrícola e o proprietário do capital industrial podem ser a mesma pessoa física ou jurídica. [...] A monopolização do território se dá através das empresas de comercialização (trading companies) e/ou processamento industrial da produção agropecuária, que não produzem diretamente no campo, porém controlam, através de mecanismos de subordinação, a produção dos camponeses e dos capitalistas produtores do campo (OLIVEIRA, 2015, 242). 
Com base nesse processo é possível identificar que na etapa da mundialização do capitalismo monopolista gestaram-se grandes empresas mundiais que hegemonizam a mundialização da agricultura brasileira: atuam sempre a favor e em benefício do grande capital financeiro, que se articula com as corporações agroindustriais denominadas por Ploeg (2008) impérios alimentares.

Os impérios alimentares são a expressão das lutas de classes e o resultado da globalização neoliberal na agricultura. Ou seja, são o atual modo capitalista de fazer agricultura. Conforme Ploeg (2008), a essência da atual fase da globalização é que ela introduz um conjunto de normas e parâmetros generalizados que passam a governar todas as práticas locais específicas. "Esse conjunto de normas generalizadas representa o núcleo do império” (PLOEG, 2008, p. 255). Tendo como padrão de funcionamento a expansão, a hierarquia e a ordem. Tratando-se de uma estrutura composta por esquemas reguladores de natureza política e econômica que são impostas à sociedade e à natureza. Com efeito, a especificidade histórica dos impérios alimentares reside na combinação contraditória e sistemática de dois princípios orientadores: o mercado global e o sistema de linha de montagem. "Combinados, esses dois princípios resultam, por exemplo, nas chamadas cadeias alimentares" (PLOEG, 2008, p. 279). Desse modo, o império estimula a monopolização das redes de produção, sobretudo de insumos, e de consumo alimentares, e dela se beneficia. Essas mudanças contribuem para vincular ainda mais a agricultura brasileira ao domínio do capital monopolista internacional, intensificando a dependência externa como marca da formação econômica do Brasil.

\section{NOTAS SOBRE A QUESTÃO AGRÁRIA}

A questão agrária consiste na interpretação crítica do desenvolvimento do capitalismo na agricultura e da sua lei geral de acumulação. Isso implica reconhecer os processos dinâmicos de formação das classes sociais na agricultura, as relações entre capital e trabalho e os conflitos resultantes dos interesses objetivos destes, que engendram as lutas de classes.

Um marco teórico muito importante da análise da agricultura a partir do marxismo é o livro A questão agrária, de Karl Kautsky, publicado em I899 (KAUTSKY, 1980). Nessa obra, o dirigente social-democrata alemão se propôs a dar continuidade às análises realizadas por Karl Marx, sobretudo ao que consta no livro III de O Capital, tratando de investigar o desenvolvimento do capitalismo na agricultura, a partir do caso alemão. Interessa-nos agora, apenas, reter a formulação geral que daí advém. Kautsky identificou que o desenvolvimento do capitalismo na agricultura seguia o padrão já observado nos processos de industrialização, congruente com a lei geral de acumulação do capital. Assim, ele identificou a particularidade econômica e tecnológica da industrialização da agricultura, em relação à agricultura camponesa, artesanal e 


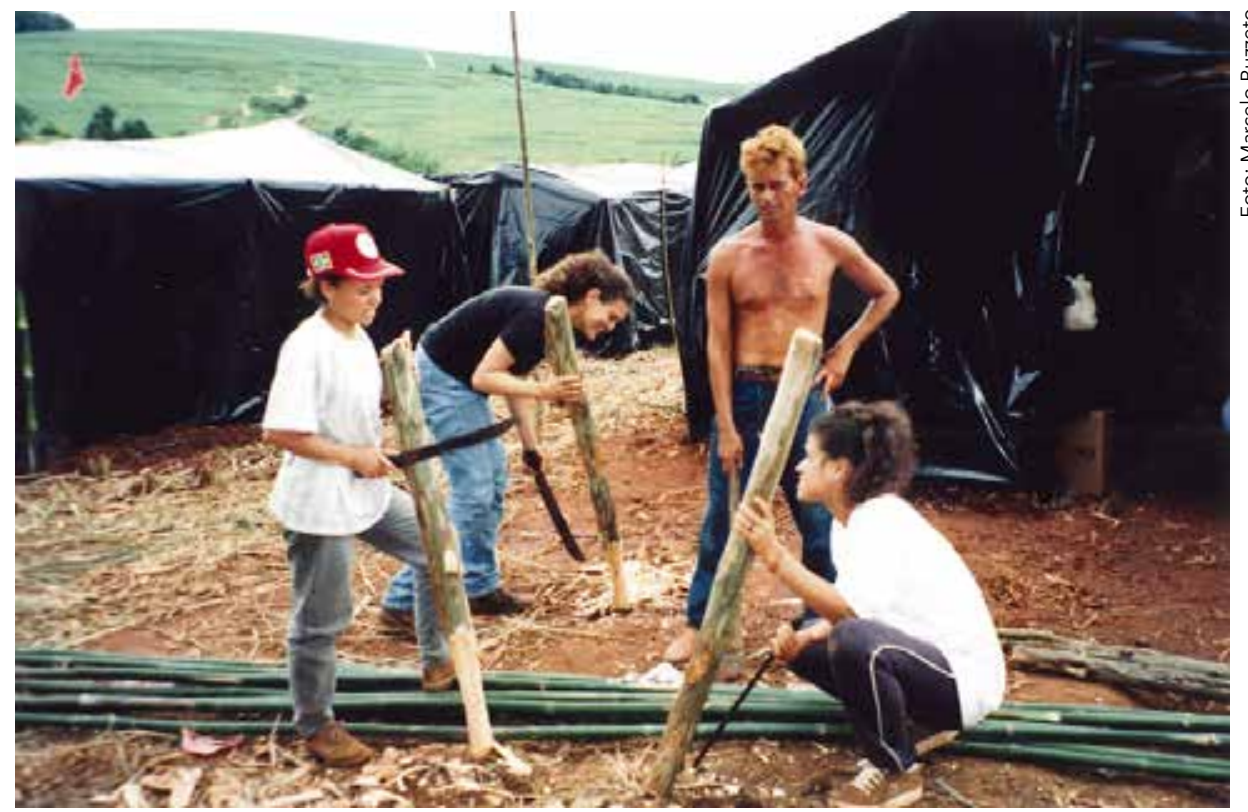

Acampamento Nova Canudos, do MST, na região de Sorocaba (SP), 1999

familiar, indicando que o movimento tendencial seria o gradativo desaparecimento da agricultura camponesa. O desenvolvimentodocapitalismopassava pelaindustrialização, pela inovação tecnológica associada à produção em larga escala na agricultura. Diante da concorrência, os camponeses tenderiam ao esgotamento de sua capacidade de se reproduzir socialmente como produtores de mercadorias.

Com efeito, Kautsky, examinando a realidade alemã, conclui que o desenvolvimento do capitalismo na agricultura desarticula o processo de trabalho camponês e pressiona pela expropriação das suas terras. Como demonstrado por Marx em O I8 brumário de Luís Bonaparte, o sistema bancário de crédito se encarregaria de expropriar os camponeses de suas terras. Uma leitura eurocêntrica, como a do marxismo dogmático presente na III Internacional (diamat), concluiu, a partir da tese do fim do campesinato, que este segmento não teria relevância e autonomia para levar adiante as lutas de classes, difundindo a consigna de que, estrategicamente, os socialistas deveriam defender o avanço da revolução burguesa no campo, acelerando a modernização capitalista do setor e fortalecendo as lutas pelos direitos trabalhistas do nascente proletariado rural. Mais amplamente, a tese do marxismo dogmático para os países ditos subdesenvolvidos era de que persistiam bolsões pré-capitalistas nessas formações econômico-sociais, e por isso a luta socialista envolveria duas etapas: a primeira, burguesa, liberal-democrática, antilatifundiária e de teor nacional, etapa que ampliaria e diferenciaria o "operariado"; a segunda seria a etapa propriamente socialista, dirigida pelo operariado industrial.

Desse modo, a contribuição de Caio Prado Jr. se destaca. O autor adquire posição de clássico do pensamento social brasileiro por sua interpretação original da 
formação social brasileira. No profícuo debate desenvolvido no âmbito do Partido Comunista do Brasil (então com a sigla PCB), Caio Prado Jr. inovou de modo muito importante na análise da questão agrária.

Entre os comunistas brasileiros predominava a interpretação segundo a qual a agricultura trazia consigo resquícios das relações sociais pretéritas ao capitalismo. Nela se identificava uma dualidade na formação social brasileira: o latifúndio agroexportador, de um lado, e o campesinato, de outro, pensados como "resquícios feudais" no campo brasileiro.

Essa opinião alicerçava-se em duas ideias. A primeira apontava para o fato de que o trabalho agrícola encontrava-se imobilizado, não se constituindo em mercadoria, devido aos vínculos personalistas e clientelistas que se estabeleciam entre grandes proprietários fundiários e lavradores dependentes, situação que ficou conhecida como coronelismo. A segunda correspondia ao entendimento de que, sob essas condições de monocultura para exportação, não se desenvolvia internamente a integração ao mercado capitalista, de consumo, de crédito e de produtos. Desse modo, a ênfase desses estudos recaía na ideia de que a agricultura, tal como estava organizada no país, representava um obstáculo ao desenvolvimento capitalista no Brasil (WEISHEIMER, 20I9, p. 82).

Caio Prado Jr. foi uma voz destoante nesse debate. O autor se opusera à interpretação feudal da agricultura brasileira. Essa posição está contida em seu estudo História econômica do Brasil, publicado em 1945, ficando plenamente desenvolvida na obra A revolução brasileira, de I966. Para o autor, o dualismo agrário no Brasil, a despeito da República, não se deu por falta do desenvolvimento capitalista, mas sim por ser o resultado de um tipo particular de desenvolvimento de um capitalismo dependente e subordinado aos interesses externos.

De um lado, o latifúndio constituía uma "exploração agromercantil" que explorava a mão de obra dos trabalhadores sem acesso à terra para "o fornecimento em larga escala de produtos primários aos mercados europeus" (PRADO JR., I969, p. II). De outro, o campesinato, descrito como "pequenos produtores que trabalham por 


\section{A tese central de Caio Prado Jr. a respeito da condição agrária era que esta se caracterizava pela dominação da grande monocultura exportadora articulada com a dinâmica internacional do capitalismo. Assim, haveria determinações gerais e exteriores sobre nossas particularidades históricas, que relacionavam o tipo de capitalismo dependente ao latifúndio agroexportador}

conta própria em terras suas ou arrendadas" (PRADO JR., I969, p. I5), estava "voltado para a produção de gêneros de subsistência da população" (PRADO JR., I969, p. I3) e convertia-se, aceleradamente, em uma forma de "assalariamento disfarçado".

Lima (1999) indica que Caio Prado Jr., ao se debruçar sobre a temática da questão agrária, estabeleceu seis grandes eixos de análise. A saber: a crítica às teses sobre o feudalismo no Brasil; a definição da questão agrária brasileira, através da análise da estrutura rural de produção; o estabelecimento da reforma agrária como tarefa do Estado nacional; análise da questão fundiária na estrutura agrária brasileira; o exame do mercado de trabalho rural em relação à estrutura agrária no Brasil; e as propostas de legislação social trabalhista para a realização da reforma agrária brasileira.

A tese central de Caio Prado Jr. a respeito da condição agrária era que esta se caracterizava pela dominação da grande monocultura exportadora articulada com a dinâmica internacional do capitalismo. Assim, haveria determinações gerais e exteriores sobre nossas particularidades históricas, que relacionavam o tipo de capitalismo dependente ao latifúndio agroexportador. Em sua obra A questão agrária, Prado Jr. (1987a), aprofundou a análise da relação contraditória entre capital e trabalho na agricultura. A partir de suas investigações da estrutura fundiária formada desde o processo de colonização do Brasil até meados da década de 1950, Caio Prado Jr. defende a tese de que a compreensão da questão agrária brasileira requer uma visão crítica da lógica do próprio desenvolvimento capitalista, correlacionando os problemas intrínsecos a esse modo de produção e reprodução da vida social no país, que tem como característica a concentração fundiária.

Caio Prado Jr. chamou a atenção para a necessidade de evolução dos padrões de vida das massas trabalhadoras agrícolas. Segundo suas palavras: "A questão prática, 
que, portanto, se propõe, é a maneira adequada às condições atuais, e nelas aplicável, de facilitar aos trabalhadores rurais o acesso à propriedade da terra" (PRADO JR., 2005, p. 80).

Em sua investigação sobre o caráter da formação social brasileira, Caio Prado Jr. buscou identificar as particularidades do seu dinamismo:

Todo povo tem na sua evolução, vista à distância, um certo "sentido". Este se percebe não nos pormenores de sua história, mas no conjunto dos fatos e acontecimentos essenciais que a constituem num largo período de tempo. Quem observa aquele conjunto, desbastando-o do cipoal de incidentes secundários que o acompanham sempre e o fazem muitas vezes confuso e incompreensível, não deixará de perceber que ele se forma de uma linha mestra e ininterrupta de acontecimentos que se sucedem em ordem rigorosa, e dirigida sempre numa determinada orientação. É isso que se deve, antes de mais nada, procurar quando se aborda a análise da história de um povo, seja aliás qual for o momento ou o aspecto dela que interessa, porque todos os momentos e aspectos não são senão partes, por si só incompletas, de um todo que deve ser sempre o objetivo último do historiador, por mais particularista que seja. Tal indagação é tanto mais importante e essencial que é por ela que se define, tanto no tempo como no espaço, a individualidade da parcela de humanidade que interessa ao pesquisador: povo, país, nação, sociedade, seja qual for a designação apropriada no caso (PRADO JR., 20II, p. I5).

A interpretação da formação social brasileira requeria a compreensão objetiva do processo colonizador português e o caráter que tomou a exploração agrária nos trópicos, realizada em larga escala, através de grandes unidades produtivas, que mobilizavam um amplo contingente de escravos, para exploração dos recursos naturais destinados à produção para exportação. "É com tal objetivo, objetivo exterior, voltado para fora do país e sem atenção a consideração que não fosse daquele comércio, que se organizarão a sociedade e a economia brasileira" (PRADO JR., I962, p. 23). Ou seja, o que caracterizaria a formação social brasileira, que vinha de sua origem colonial, era que sua economia se destinava, sobretudo, ao abastecimento do mercado internacional com produtos primários típicos das lavouras tropicais.

Ao sustentar esse raciocínio, Caio Prado Jr. observa a precariedade da situação dos trabalhadores rurais, que deveria ser respondida com uma melhor repartição da propriedade agrária. Ressalta, ainda, que os entraves à reforma agrária não decorriam dos supostos resquícios feudais, mas da dominação capitalista e seu padrão de acumulação. Assim, essa estrutura fundiária estaria a serviço da reprodução de condicionantes fundamentais do capitalismo dependente, quais sejam: o controle do capital internacional sobre os elos estratégicos da economia e a perpetuação da segregação social, servindo de base para a formação da sociedade nacional, o que por sua vez trará consequências nos âmbitos econômico, social e político. "As condições econômicas fundamentais do país e a estrutura social que sobre elas se construiu 
tornavam evidentemente inviável uma organização agrária democrática e de larga repartição da propriedade fundiária” (PRADO JR., I962, p. 255). Com base nessa crítica o historiador estabeleceu uma avaliação positiva para as formas de pequenas propriedades agrícolas destinadas ao abastecimento do mercado interno.

Ele ressalta as diferenças entre duas formas de agricultura familiar e camponesa que emergiram entre as regiões Sul e Norte/Nordeste do Brasil. A primeira, resultante do processo de migração europeia e colonização do Sul do Brasil. "Ali o grande progresso da pequena propriedade nos estados meridionais deve-se sobretudo ao fato de ela não ter sofrido a concorrência de nenhuma grande lavoura tropical” (PRADO JR., I962, p. 257). Já nas regiões do Nordeste brasileiro, a pequena propriedade aparece como resultado do processo de desagregação do sistema da lavoura de exportação, a partir da dissolução e retalhamento de grandes fazendas. Podemos reter a compreensão de que, para Caio Prado Jr., a pequena propriedade aparece como antítese do latifúndio. Assim, a sua ampliação "representa um golpe profundo desferido na estrutura agrária tradicional do Brasil" (PRADO JR., I962, p. 258). Por outro lado, à medida que se fortalece o sistema agroexportador e a grande propriedade se expande, simultaneamente se reduzem as possibilidades de consolidação da agricultura de base familiar voltada para o abastecimento interno da população nacional, atualizando a luta pela reforma agrária.

\footnotetext{
É que quando a grande exploração se fortalece e prospera ou, em outras palavras, se torna rendoso "negócio", ela tende a se ampliar e absorver um máximo de extensão territorial e de força de trabalho, [... reduzindo o espaço para] os trabalhadores de outras atividades. Inversamente, é na medida em que se deteriora o negócio que a grande exploração realiza que ela se torna menos exigente e é obrigada a fazer maiores concessões àquelas atividades secundárias que se desenvolvem à sua sombra (PRADO JR., 198I, p. 53).
}

Assim, diferentemente dos marxistas dogmáticos, Prado Jr. compreendeu que os anacronismos e a coexistência de formas distintas de organização e de exploração do trabalho não advinham da persistência feudal, salientando que o modo de produção capitalista não é um movimento teleológico destinado a suprimir a existência da agricultura camponesa. O desenvolvimento desigual e as lutas sociais são dimensões constitutivas da questão agrária.

Como propugnado por Florestan Fernandes em $A$ revolução burguesa no Brasil (FERNANDES, 2008), a revolução burguesa no Brasil não se deu na forma "clássica", como nos EUA, em que a reforma agrária se deu por rupturas e lutas de grande intensidade. Em seu escrito político Repensando a revolução burguesa no Brasil (escrito originalmente em 1979 e republicado pela Editora UFRJ em 20II), Fernandes destaca: "as burguesias associadas e dependentes são incapazes de fomentar e dirigir as três grandes revoluções (a nacional, a industrial e a democrática) que definiram o significado construtivo do chamado capitalismo clássico" (FERNANDES, 20II, p. IOo). 


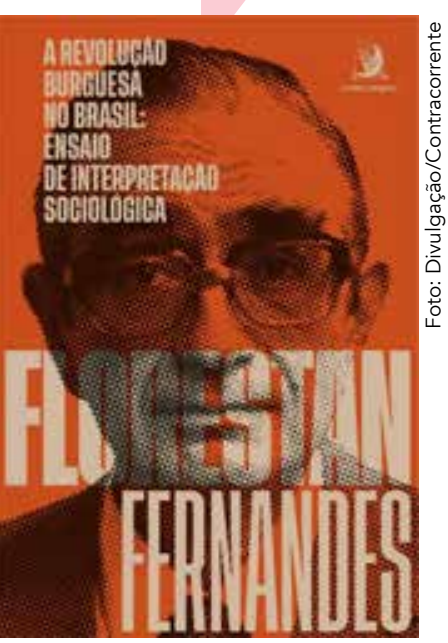

$\Delta$ Capa da sexta edição do livro A revolução burguesa no Brasil (1974), de Florestan Fernandes, lançada em 2020 pela editora Contracorrente.

40 historiador, geógrafo, filósofo e político paulistano Caio Prado Jr. (1907-1990)

Um breve exame dos projetos patrocinados e dos votos da dita bancada ruralista Frente Parlamentar Agropecuária e as orientações do Instituto Pensar Agropecuária (ROHDEN, s.d.) - confirma a persistência das pautas e agendas (SILVA, 20I7) que contrastam com a imagem veiculada pelas frações que atuam no segmento de maior sofisticação tecnológica, a exemplo da Abag.

Como salienta Fernandes (I98I; 2008), as frações burguesas de maior relevância na formação econômica e social brasileira são associadas, subordinadas, dependentes em relação ao núcleo hegemônico do capital. Isso não as torna irrelevantes do ponto de vista da reprodução do capital. São parceiras menores, mas parceiras, e exercem intenso protagonismo na efetivação das condições de extração de mais-valia direta (inclusive por meio do Estado) e, também, na apropriação do fundo público.

Desse modo, a questão agrária não pode deixar de ser investigada como parte das lutas de classes e dos embates entre as frações de classes. Se concebida como persistência de um passado que se faz presente, o risco é pensá-la como um objeto cujo epicentro de força motriz já foi superado pelas novas configurações do capitalismo no campo. Nesse sentido, as contribuições originais de Caio Prado Jr. e de Florestan Fernandes são relevantes: na trilha aberta por Caio Prado Jr., a questão agrária é uma dimensão da problemática do modo de produção capitalista e, nos termos de Florestan Fernandes (2008), uma problemática não contemplada pela revolução burguesa sui generis do Brasil.

Por conseguinte, teórica e metodologicamente é obrigatório examinar a luta dos trabalhadores do campo, em sentido amplo, a partir dos anos I950, na conformação da particularidade da questão agrária brasileira (como então pensada pela esquerda), e, correlatamente, como ela se conformou nos governos progressistas. 


\section{A questão agrária não pode deixar de ser investigada como parte das lutas de classes e dos embates entre as frações de classes. Se concebida como persistência de um passado que se faz presente, o risco é pensá-la como um objeto cujo epicentro de força motriz já foi superado pelas novas configurações do capitalismo no campo}

\section{A QUUESTÃO AGRÁRIA NA LUTA DOS CAMPONESES E DOS TRABALHADORES DO CAMPO}

Nos anos 1950 a irrupção de importantes lutas camponesas inscreveu na agenda política a questão agrária no Brasil. O problema a ser superado estava na concentração fundiária e nas relações entre o trabalho e o capital, desprovidas de direitos legais para os trabalhadores agrícolas. Isso se refletiu na formação das primeiras organizações sindicais de trabalhadores agrícolas no país. Nesse período, ocorre a criação da União dos Lavradores e Trabalhadores Agrícolas do Brasil (Ultab), impulsionada pelos comunistas em I954 no centro-sul do país. Houve ainda a formação das Ligas Camponesas em I955, em Pernambuco, expandindo-se para o restante do Nordeste brasileiro, com a liderança de Francisco Julião, eleito deputado estadual pelo Partido Socialista Brasileiro (PSB) em Pernambuco. Também houve o Movimento dos Agricultores Sem Terra (Master), no Rio Grande do Sul, criado em I960 e ligado às lideranças do Partido Trabalhista Brasileiro (PTB), como o então governador Leonel Brizola. Esse processo converge, mais tarde, para a fundação da Confederação Nacional dos Trabalhadores na Agricultura (Contag) em I963, reunindo 29 federações e 475 sindicatos.

Isso se refletiu na intensificação das lutas sociais no campo, que resultariam em conquistas legais como a promulgação da lei federal $n^{\circ} 4.214 / 1963$, o Estatuto do Trabalhador Rural, estendendo a legislação social ao trabalhador da agricultura. Essas lutas também forneceram as bases para a legalização da organização sindical dos trabalhadores na agricultura, por meio do decreto-lei $n^{\circ}$ 53.5I7, de 31 de janeiro de 1964 , reconhecendo a Contag como a confederação nacional de todos os trabalhadores da agricultura. Caio Prado Jr. destacou a importância dessas conquistas, principalmente a do Estatuto do Trabalhador Rural. 
Merece destaque que, no breve governo João Goulart (PTB), de I96I a I964, a reforma agrária passou a integrar os objetivos do governo federal, integrando o Plano Trienal, de I963. A proposta de reforma agrária do plano estabelecia que:

a) nenhum trabalhador que, durante um ciclo agrícola completo, tiver ocupado terras virgens e nelas permanecido sem contestação será obrigado a pagar renda sobre a terra economicamente utilizada; b) nenhum trabalhador agrícola, foreiro ou arrendatário por dois ou mais anos em uma propriedade poderá ser privado de terras para trabalhar, ou de trabalho, sem justa indenização; c) nenhum trabalhador que obtiver da terra em que trabalha - ao nível da técnica que lhe é acessível - rendimento igual ou inferior ao salário mínimo familiar, a ser fixado regionalmente, deverá pagar renda sobre a terra, qualquer que seja a forma que esta assuma; d) todas as terras, consideradas necessárias à produção de alimentos, que não estejam sendo utilizadas ou o estejam para outros fins, com rendimentos inferiores às médias estabelecidas regionalmente, deverão ser desapropriadas para pagamento a longo prazo (PRESIDÊNCIA DA REPÚBLICA, I962, p. 194-I95 apud BERCOVICI, 2020, p. 219).

O Congresso Nacional rechaçou a proposta de reformas, em meio a crescentes manifestações populares. O que culminou na realização do "Comício das Reformas", em I3 de março de I964, que reuniu importantes representações de classe e organizações políticas que defendiam as chamadas "reformas de base". No comício, o presidente João Goulart assinou o decreto no 53.700, em que considerava de interesse social, passíveis de desapropriação pelo Estado, os imóveis de mais de 500 hectares situados a até dez quilômetros da margem das rodovias, ferrovias e açudes (CAMARGO, I99I). A resposta das classes dominantes à proposta de reforma agrária de João Goulart e ao movimento reformista veio no dia $\mathrm{I}^{\circ}$ de abril de 1964 , na forma de um golpe empresarial-militar, que instaurou uma ditadura que somente foi interrompida com a Constituição Federal de 1988.

Os anos I960 e I970 foram marcados pela intensificação das políticas de "modernização da agricultura", o que significou a implementação de um novo paradigma tecnológico (a chamada "revolução verde") promovido pelas forças que movem o capitalismo monopolista, sempre com forte atuação do Estado. $\mathrm{O}$ governo brasileiro investiu grandes volumes de subsídios na agricultura através do crédito rural e do suporte à pesquisa agropecuária nas universidades públicas e na Embrapa e afins, privilegiando os produtos destinados à exportação e beneficiando, predominantemente, os grandes produtores. Com o programa de crédito rural subsidiado, o governo interveio no sistema de preços relativos, com políticas de formação de estoques reguladores e medidas protecionistas tanto no mercado de produtos como no de insumos (MARTINE, I987). A concessão de créditos maiores para propriedades mais extensas encorajou a concentração de terra. A política de "modernização" também provocou mudança nas relações de trabalho no campo: a força de trabalho dos arrendatários residentes nas fazendas foi substituída, em 
determinados setores, pela força de trabalho assalariada temporária (DEERE, 2003). Essas mudanças introduziram um novo padrão tecnológico (a rigor, a chamada "revolução verde" ultrapassa, em muito, as mudanças tecnológicas, envolvendo o mercado mundial de commodities, processos de formação, estratégias políticas etc.) para a agricultura, tornando ainda mais profundo o fosso entre as classes rurais de altas e baixas rendas e contribuindo para agravar as contradições da agricultura capitalista (GUIMARÃES, I979).

Na década de I980, sobressaíram as discussões em torno do grau de “integração" e "exclusão" das pequenas propriedades em relação aos complexos agroindustriais. Consideravam-se como integrados os agricultores que tinham sua produção agrícola voltada às demandas da agroindústria e do mercado consumidor. Por sua vez, os agricultores "excluídos" eram aqueles cuja produção não estava voltada aos complexos agroindustriais e que não haviam incorporado os processos de modernização agrícola (PORTO; SIQUEIRA, I994). Outra novidade desse período é a emergência de novos sujeitos e movimentos sociais no campo. Destacam-se as questões trazidas pela retomada das lutas pela reforma agrária e pelo reconhecimento dos direitos sociais e trabalhistas para as mulheres, como produtoras rurais (WEISHEIMER, 20I9).

No que se refere aos conflitos sociais agrários, o início dos anos I980 marca a emergência de novos movimentos de luta pela terra. Ainda na década de I970, influenciada pelo Concílio Vaticano II e pela teologia da libertação, a Igreja Católica promoveu a formação das comunidades eclesiais de base (CEBs) e criou a Comissão Pastoral da Terra (CPT), em 1975. Essas iniciativas convergiram para a constituição do Movimento dos Trabalhadores Rurais Sem Terra (MST), em janeiro de I984, que em poucos anos se expandiu pelo território nacional. Esse movimento se destacou pela incorporação às suas táticas de lutas de ocupação de terras, materializadas em acampamentos e ocupações em grandes fazendas improdutivas e com títulos protestados, bem como pela negociação com o Estado para a desapropriação dessas terras em favor dos trabalhadores e pela regularização destes nas áreas de assentamento de reforma agrária, conforme destaca Araújo (202I).

Entre os anos de 1990 e 1999 as ocupações cresceram de 50 para 856 (DATA LUTA, 2017 apud CATTELAN, MORAES; ROSSONI, 2020). Como resultado, nos anos I990, o Estado brasileiro intensificou a implantação de assentamentos de reforma agrária, passando de 42,9 mil famílias assentadas para IoI mil no mesmo período (CATTELAN, MORAES; ROSSONI, 2020) e aumentando, dessa forma, o quantitativo de famílias assentadas.

Entretanto, o agronegócio, por diversos fatores, ganhou nova dimensão na agenda econômica mundial, sobretudo pela força das demandas chinesas e pela crescente financeirização do segmento, tornando-se, em toda a sua diversidade, uma força econômica de grande magnitude. E, com isso, o processo de reforma agrária apresentou forte regressão ao longo dos anos 2000. Quando Lula da Silva assumiu a Presidência da República, a expectativa era de que houvesse um período virtuoso 

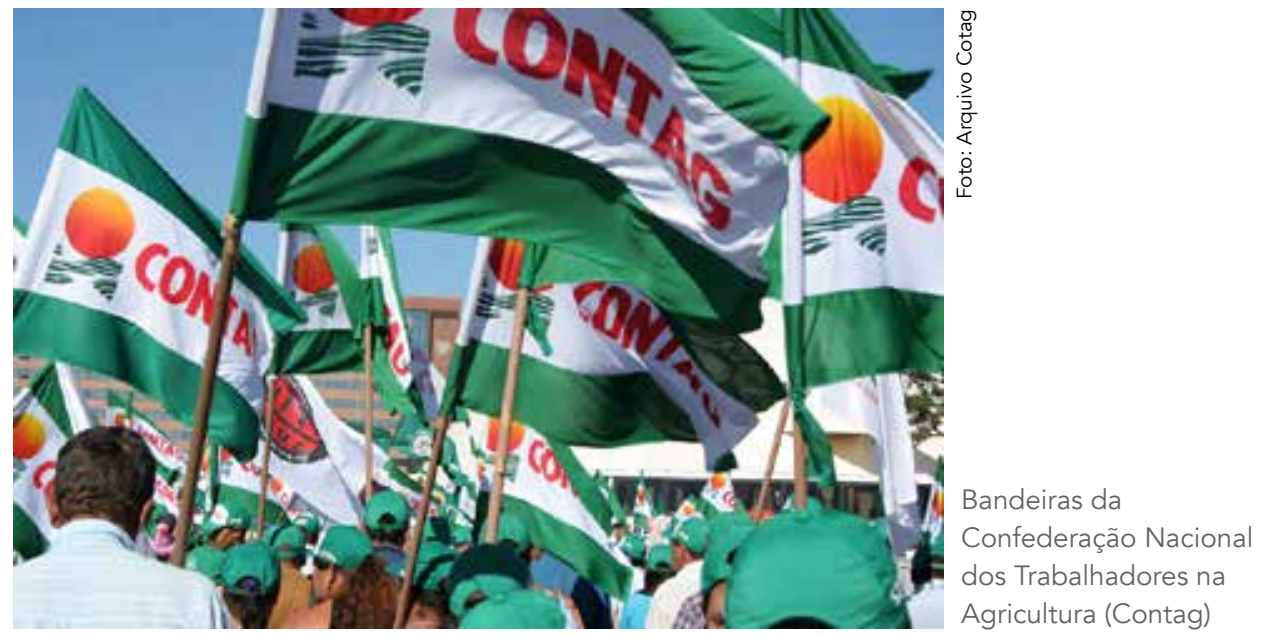

para a reforma agrária (que se verificou parcialmente em seu primeiro mandato) e de fortalecimento sustentável da agricultura familiar por meio do Programa Nacional de Fortalecimento da Agricultura Familiar (Pronaf). Nesse contexto, ocorreu o lançamento do II Plano Nacional da Reforma Agrária, durante a Conferência da Terra, em 2003. Contudo, predominaram os marcos das políticas neoliberais de reforma agrária via mercado, através de políticas de crédito e financiamento para os agricultores, tais como os propostos e financiados pelo Banco Mundial no Programa Nacional de Crédito Fundiário (PNCF), responsável pela gestão do Crédito Fundiário e do Fundo de Terras no Brasil.

No primeiro mandato de Lula da Silva as ocupações de terra foram retomadas, passando de 269 em 2002 para 539 em 2003, 662 em 2004 e 56I em 2006. No segundo governo Lula a média de ocupações foi de 515 por ano; no primeiro mandato de Dilma Rousseff, período de aproximação com a Confederação Nacional da Agricultura (CNA), a média foi de 242 por ano. Com isso, a média de famílias assentadas por ano no primeiro mandato de Lula foi de $95 \mathrm{mil}$, e, no segundo mandato, de 58,2 mil; a partir daí a queda foi ainda mais acentuada: no mandato de Dilma Rousseff, 26,7 mil, decaindo ainda mais no governo Temer, para 3,4 mil famílias assentadas. O governo Bolsonaro interrompe de vez os assentamentos (CATTELAN, MORAES; ROSSONI, 2020, p. I42-I43). Ademais, as condições concretas dos assentamentos apresentaram carências diversas, destacadamente no que concerne ao acesso às demais políticas sociais, como crédito rural, extensão rural, saúde, lazer e educação, por exemplo, desconsiderando inclusive as particularidades regionais e locais e evidenciando equívocos em sua implantação (MIRALHA, 2006).

No capitalismo dependente, a reforma agrária não assume lugar de objetivo nacional. O que ocorreu no Brasil foi a implementação de uma política de acesso à propriedade de terras para agricultores familiares via emissão de títulos, assegurando aos grandes proprietários latifundiários indenizações a preço de mercado e, assim, ganhos de capital. Tais políticas, entretanto, não garantem condições necessárias 
para que os agricultores familiares assentados possam produzir e se reproduzir socialmente na agricultura. $\mathrm{O}$ resultado tem sido a baixa efetividade dessas políticas em promover uma distribuição democrática da terra. Conforme salienta destacada liderança do MST, João Pedro Stedile:

É importante esclarecer que não consideramos esses assentamentos como um processo de reforma agrária. Reforma agrária, no nosso modo de entender, seria se houvesse uma medida mais ampla e massiva que conseguisse frear a concentração da propriedade da terra e de fato distribuir a propriedade da terra. Mesmo com esses assentamentos, nesses I5 anos, o processo de concentração da propriedade da terra no Brasil continua, de maneira que não vivenciamos uma reforma agrária na sua essência. Estamos distribuindo terras apenas para resolver problemas sociais e não como uma política, um programa de reforma agrária mais amplo (STEDILE, 1997, p. 73).

Observa-se que a questão agrária brasileira expressa a ausência de uma revolução burguesa clássica, na qual a reforma agrária concorre para a "modernização" e o fortalecimento de um projeto autopropelido de nação. Historicamente, a reforma agrária tem possibilitado a formação do campesinato integrado ao desenvolvimento do mercado interno das nações, especialmente na produção de alimentos e geração de excedentes que financiam a industrialização. Os obstáculos à reforma agrária são entraves à reprodução social das formas familiares de agricultura, ao desenvolvimento do mercado interno e à reprodução das forças produtivas, com alimentos de menor custo e saudáveis.

\section{CONSIDERAÇÕES FINAIS}

Com o regime de acumulação neoliberal, a burguesia agrária intensificou seus vínculos com as frações burguesas hegemônicas, favorecendo a articulação de um bloco no poder formado por capitalistas do agronegócio e de segmentos agroindustriais, financeiros e do comércio varejista de alimentos. Em decorrência disso, a concentração fundiária torna-se funcional à nova ordem capitalista contemporânea, sendo operada por um acordo entre as frações da classe dominante no poder. Essa apropriação do Estado nacional impõe uma "democracia restrita", que se caracteriza por políticas agrícolas que beneficiam o grande capital agrário exportador, garantindo elevada rentabilidade aos investimentos planejados e financiados por frações burguesas locais associadas às grandes corporações multinacionais. Com efeito, a expansão do agronegócio acarreta o aumento do preço da terra, sua concentração e monopolização. A consequência dessa expansão é a intensificação do processo de espoliação de agricultores familiares.

Tal dinâmica intensifica o controle do capital internacional sobre os ativos e recursos naturais, com destaque para as fontes hídricas, e sobre as dinâmicas territoriais, as cadeias produtivas e os sistemas de produção na agricultura. Com isso, a ocupação do território e a produção agropecuária passam a serem definidos, majo- 


\section{Entendemos que, para a superação} do capitalismo dependente, do "subdesenvolvimento", da pobreza e da fome é indispensável a democratização da propriedade da terra, com uma efetiva reforma agrária no Brasil. Contudo, considerando que a burguesia brasileira está comprometida como sócia menor da exploração imperialista, essa é uma tarefa que só poderá ser concluída pelas classes trabalhadoras, urbanas e rurais

ritariamente, não por estratégias nacionais, mas pelo fluxo das demandas internacionais das cadeias de produção e das transferências de valor na agricultura. Essas novas formas de dominação da natureza e do trabalho por grandes conglomerados agroalimentares internacionais exacerbam as contradições entre, de uma parte, os agricultores familiares e os trabalhadores assalariados, e, de outra, os operadores do agronegócio que objetivam a reprodução ampliada do capital na agricultura contemporânea.

Buscamos apresentar os elementos que formam a compreensão crítica da questão agrária no Brasil como particularidade da nossa formação econômica e social. Recorremos ao pensamento social marxista, com destaque para as contribuições teóricas de Caio Prado Jr., Florestan Fernandes e seus intérpretes. O que nos permitiu tecer um argumento que vincula a questão agrária, caracterizada pela grande propriedade, a uma formação social tipificada como capitalismo dependente, residindo nessa dependência a razão do nosso "subdesenvolvimento" como nação. Logo, o desenvolvimento econômico-social nacional depende em grande parte da efetivação da reforma agrária, referenciada em outro modelo de agricultura, como condicionante estrutural para a transformação da sociedade brasileira.

As sínteses analíticas da questão agrária no âmbito do marxismo objetivam e possibilitam a interpretação da particularidade do processo de desenvolvimento do capitalismo na agricultura. Contudo, isso não está restrito a uma agenda de construção do conhecimento científico sobre a realidade nacional, por ser parte da luta política de acumulação de forças a favor da soberania nacional e da luta pelo socialismo. Nos países do Sul global, de passado colonial e escravista, onde se perpetuam formas de capita- 
lismo dependente, como o Brasil, a questão agrária é indissociável das questões nacional e social. Situa-se como elemento estruturante da formação econômica e social e, ao mesmo tempo, é estruturada por ela, havendo uma mútua determinação entre ambas.

O que temos é a proeminência do latifúndio exportador, envolvendo complexas cadeias produtivas, agentes financeiros e fundos de investimento; equipamentos, insumos, basicamente importados em dólar; sementes transgênicas com genes terminator; logística de transporte local e intercontinental; transformação de alimentos em commodities sob o controle de impérios alimentares, assim como, no âmbito nacional, a elaboração de estratégias de capacitação de trabalhadores e difusão de ideologias em prol do "agro", alcançando escolas e universidades, a exemplo dos citados programas "Agrinho", "Sou agro", "Agro é tech, agro é pop, agro é tudo" etc., tudo isso formulado e difundido através de complexos e cambiantes aparelhos privados de hegemonia que, em seu conjunto, intensificam as formas de subordinação, diretas e indiretas, do trabalho ao capital na agricultura e da soberania alimentar da nação aos interesses dos impérios alimentares.

Esse processo de concentração do capital na agropecuária segue associado à destruição de biomas e ecossistemas, à elevada emissão de carbono, a um regime alimentar nada saudável e que transfere a soberania alimentar da nação para impérios alimentares, assim como a processos de brutais expropriação e exploração do trabalho. As formas de trabalho escravo das grandes plantations foram substituídas por mecanismos de dependência e servidão no coronelismo e, em tempos atuais, compreendem diferentes tipos de relações de trabalho precário, que reproduzem a exploração de trabalhadores livres em grandes fazendas exportadoras. Ou seja, a exploração capitalista mobiliza amplamente formas de trabalho "assalariado" e mistas, marcadas pela precariedade e informalidade das relações de trabalho nas empresas agrícolas, agropecuárias e agroflorestais. Objetivando a manutenção desse padrão de exploração, influentes APHs do setor trabalham diuturnamente para ampliar e consolidar a autocracia burguesa. Enquanto isso, os agricultores familiares em busca de autonomia e reprodução social procuram resistir à dinâmica de concentração com diferentes estratégias produtivas e de integração aos mercados, intensificando sua diferenciação social interna. Essas relações de produção na agricultura apresentam grandes assimetrias e diferenciações em que coexistem relações de produção arcaicas e modernas. A resultante desse padrão de acumulação é a perpetuação da dependência externa, do "subdesenvolvimento", das abissais desigualdades e da pobreza extrema.

Evidencia-se a atualidade da questão agrária na determinação do caráter da formação social brasileira. Na contemporaneidade, os problemas agrários decorrentes da relação capital-trabalho no campo podem ser evidenciados pelo desemprego estrutural e conjuntural; pelo chamado êxodo rural forçado para o território urbano, principalmente de jovens, por conta da desesperança na reprodução social da agricultura familiar, devido à falta de condições materiais de sobrevivência. Sobre esse último aspecto, o fechamento de escolas do campo é uma das expressões mais 
graves e nefastas desse processo de apropriação dos territórios rurais por grandes corporações agropecuárias. É, inclusive, com base na compreensão da atualidade e da particularidade da questão agrária que o problema da educação no campo poderá ser enfrentado com a força e a escala necessária. Acrescenta-se o enfrentamento do negacionismo climático, a defesa do bem viver das populações rurais, a soberania e a segurança alimentar de toda a nação.

Entendemos que, para a superação do capitalismo dependente, do "subdesenvolvimento", da pobreza e da fome é indispensável a democratização da propriedade da terra, com uma efetiva reforma agrária no Brasil. Contudo, considerando que a burguesia brasileira está comprometida como sócia menor da exploração imperialista, essa é uma tarefa que só poderá ser concluída pelas classes trabalhadoras, urbanas e rurais. Levada a bom termo, essa tarefa destravará o objetivo inconcluso de nossa formação social, isto é, a transformação do Brasil, de Estado servil, em nação soberana e comprometida com o bem viver de seu povo.

* Doutor em Sociologia pela Universidade Federal do Rio Grande do Sul (UFRGS). Professor associado da Universidade Federal do Recôncavo da Bahia (UFRB) e professor permanente do Programa de Pós-Graduação em Ciências Sociais (PPGCS) Cultura, Desigualdade e Desenvolvimento, da UFRB. Líder dos grupos de pesquisa do CNPq: Núcleo de Estudos em Agricultura Familiar e Desenvolvimento Rural (Neaf) e Observatório Social da Juventude (OSJ), da UFRB. Editor-executivo da revista Princípios. Vencedor do Prêmio Capes de Teses de Sociologia em 2010. ID Orcid: http://orcid.org/0000-0002-6320-8402; ID Lattes: http://lattes.cnpq.br/8189989792551322. E-mail: nw65br@gmail.com

** Mestra em Políticas Públicas pela Universidade Federal do Maranhão (UFMA). Funcionária pública da rede estadual de ensino do Maranhão (SeducMA). Ex-coordenadora-executiva do Comitê Executivo Estadual de Educação do Campo do Maranhão (2016-2018). Pesquisadora do Grupo de Estudo sobre Política, Lutas Sociais e Ideologias (Gepolis) e do Grupo de Pesquisa em Desenvolvimento Econômico e Agricultura no Brasil (Deab), da UFMA. ID Orcid: http://orcid.org/0000-0002-0207-3487; ID Lattes: http://lattes.cnpq. br/6291232931056258.E-mail: michelle.sena.slz@gmail.com

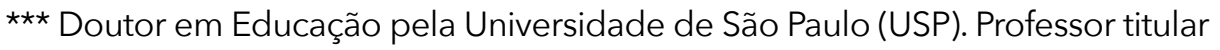
da Faculdade de Educação e do Programa de Pós-Graduação em Educação da Universidade Federal do Rio de Janeiro (UFRJ), desenvolve pesquisa em políticas públicas em educação. Atua no Coletivo de Estudos em Marxismo e Educação (Colemarx). Pesquisador do CNPq. Colaborador da Escola Nacional Florestan Fernandes (ENFF). ID Orcid: http://orcid.org/0000-0002-5063-8753; ID Lattes: http://lattes.cnpq.br/6873414697016839.E-mail: leher.roberto@gmail.com 
ABAG. Agronegócio faz manifesto pela democracia. 8 set. 2021. Disponível em: <https://abag. com.br/agronegocio-faz-manifesto-pela-democracia>. Acesso em: 19 nov. 2021.

ARAÚJO, Michelle Sena Rosa de. Poder político e ação política do MST por educação do campo no Brasil em tempos de negacionismo dos direitos sociais. Princípios, v. 40, n. 161, p. 245-269, mar.-jun. 2021.

Relação do Movimento dos Trabalhadores Rurais Sem Terra - MST - com o Estado na construção de políticas públicas de educação do campo no Maranhão (2003-2016). 2019. 187f. Dissertação (Mestrado em Políticas Públicas) — Programa de Pós-Graduação em Políticas Públicas, Universidade Federal do Maranhão, São Luís, 2019.

BERCOVICl, Gilberto. A questão agrária na era Vargas (1930 -1964). História do Direito, v. 1, n. 1, p. 183-226, dez. 2020. Disponível em: <https://revistas.ufpr.br/historiadodireito/article/view/78725>. Acesso em: 30 maio 2021.

CAMARGO, Aspásia Alcântara de. A questão agrária: crise de poder e reformas de base (1930-1964). In: FAUSTO, Boris. (Coord.). História geral da civilização brasileira. Rio de Janeiro: Bertrand Brasil, 1991. v. 10, t. 3, p. 121-224.

CANAN, Adriane et al. Além da covid, Bolsonaro espalha a pandemia da fome, alertam camponesas. Brasil de Fato, 7 jun. 2021. Disponível em: <www.brasildefato.com.br/2021/06/07/artigo-alem-da-covid-bolsonaro-espalha-a-pandemia-da-fome-alertam-camponesas>. Acesso em: 20 nov. 2021.

CATTELAN, Renata; MORAES, Marcelo Lopes de; ROSSONI, Roger Alexandre. A reforma agrária nos ciclos políticos do Brasil (1995-2019). Revista Nera, Presidente Prudente, v. 23, n. 55, p. 138-164, set.-dez. 2020.

CEPEA. PIB Agro/Cepea: com avanço de $24,3 \%$ no ano, PIB Agro alcança participação de $26,6 \%$ no PIB brasileiro em 2020. Piracicaba, 11 mar. 2021. Disponível em: <https://cepea.esalq.usp.br/br/ releases/pib-agro-cepea-com-avanco-de-24-3-no-ano-pib-agro-alcanca-participacao-de-26-6-no-pib-brasileiro-em-2020.aspx>. Acesso em: 19 nov. 2021.

CHESNAIS, François. A mundialização do capital. São Paulo: Xamã, 1996.

DEERE, Carmen Diana. Women's land rights and rural social movements in the Brazilian agrarian reform. Journal of Agrarian Change, v. 3, n. 1-2, p. 257-288, Jan.-Apr. 2003.

FERNANDES, Florestan. A revolução burguesa no Brasil: um ensaio de interpretação sociológica. São Paulo: Globo, 2008.

Brasil: em compasso de espera. Rio de Janeiro: Editora UFRJ, 2011.

Sociedade de classes e subdesenvolvimento. 4. ed. Rio de Janeiro: Zahar, 1981.

GUIMARÃES, Alberto Passos. A crise agrária. Rio de Janeiro: Paz e Terra, 1979.

IBGE. Síntese de Indicadores Sociais. 2021. Disponível em: <https://agenciadenoticias.ibge.gov.br/ agencia-sala-de-imprensa/2013-agencia-de-noticias/releases/32418-sintese-de-indicadores-sociais-em-2020-sem-programas-sociais-32-1-da-populacao-do-pais-estariam-em-situacao-de-pobreza>. Acesso em: 3 dez. 2021.

KAUTSKY. Karl. A questão agrária. São Paulo: Proposta, 1980.

LAMOSA, Rodrigo de Azevedo Cruz; LOUREIRO, Carlos Frederico Bernardo. Agronegócio e educação: o trabalho docente e a pedagogia da hegemonia. Cadernos de Educação, n. 60, 2018.

LEHER, Roberto. Florestan Fernandes e a universidade no capitalismo dependente. In: FÁVERO, Osmar (Org.). Democracia e educação em Florestan Fernandes. Campinas: Autores Associados; Niterói: Editora da UFF, 2005. p. 100- 125.

LEHER, Roberto. Florestan Fernandes e o sentido socialista do público. Rio de Janeiro: Editora UFRJ, 2015.

LIMA, Rodne de Oliveira. Caio Prado Júnior e a questão agrária no Brasil. Geografia, Londrina, v. 8, n. 2, p.123-134, jul.-dez. 1999.

MARTINE, George; ARIAS, Afonso Rodrigues. Modernização e emprego no campo. In: MARTINE, George; GARCIA, Ronaldo Coutinho (Org.). Impactos sociais da modernização conservadora. São 
Paulo: Caetés, 1987. p. 59- 79.

MARX, KARL. Capítulo VI inédito de O Capital. São Paulo: Centauro, 2004.

O Capital: crítica da economia política. São Paulo: Difel, 1985.

MENDONÇA, Sonia Regina de. O ruralismo brasileiro. São Paulo: Hucitec, 1997.

MIRALHA, Wagner. Questão agrária brasileira: origem, necessidade e perspectivas de reforma hoje. Revista Nera, Presidente Prudente, v. 9, n. 8, jan.-jun. 2006.

OLIVEIRA, Ariovaldo Umbelino. A mundialização do capital e a crise do neoliberalismo: o lugar mundial da agricultura brasileira. Geousp - Espaço e Tempo, v. 19, n. 2, p. 229-245, ago. 2015. Disponível em: <www.revistas.usp.br/geousp/article/view/102776/105612>. Acesso em: 30 maio 2021.

PLOEG, Jan Douwe van der. Camponeses e império alimentares: lutas por autonomia e sustentabilidade na era da globalização. Porto Alegre: Editora UFRGS, 2008.

POMPEIA, Caio. O agrobolsonarismo. Piauí, jan. 2022. Disponível em: <https://piaui.folha.uol.com. br/materia/o-agrobolsonarismo>. Acesso em: 9 jan. 2022.

PORTO, Maria S. Grossi; SIQUEIRA, Deis E. A pequena produção do Brasil: entre os conceitos teóricos e as categorias empíricas. Cadernos de Sociologia, Porto Alegre, n. 6, p. 76-88, 1994.

PRADO JR., Caio. A questão agrária. 1. ed. São Paulo: Brasiliense, 1987a.

A questão agrária e a revolução brasileira. In: STEDILE, João Pedro (Org.). A questão agrária no Brasil. São Paulo: Expressão Popular, 2005. v. 1.

A revolução brasileira. São Paulo: Brasiliense, 1978.

Contribuição para a análise da questão agrária brasileira. In:

Agricultura subdesen-

volvida. Petrópolis: Vozes, 1969.

Formação do Brasil contemporâneo. 20. ed. São Paulo: Brasiliense, 1987b.

História econômica do Brasil. 2 ed. São Paulo: Brasiliense, 1962.

O sentido da colonização. In: Formação do Brasil contemporâneo. São Paulo: Companhia das Letras, 2011.

ROHDEN, Júlia; LOBO, Matheus. Especial: sob ataque da bancada ruralista. Brasil de Fato, s.d. Disponível em:<www.brasildefato.com.br/especiais/especial-or-sob-ataque-da-bancada-ruralista $>$. Acessado em: 19 nov. 2021.

SAMPAIO JR., Plínio de Arruda. Entre a nação e a barbárie: uma leitura das contribuições de Caio Prado Jr., Florestan Fernandes e Celso Furtado à crítica do capitalismo dependente. 1997. Tese (Doutorado em Economia Aplicada) — Universidade de Campinas, Campinas, 1997.

Notas críticas sobre a atualidade e os desafios da questão agrária. 2012. Disponível em: <https://mst.org.br/2012/11/07/notas-criticas-sobre-a-atualidade-e-os-desafios-da-questao-agraria>. Acesso em: 1 abr. 2018.

SILVA, Elizângela Cardoso de Araújo. Conservadorismo, bancada ruralista e indígenas. Temporalis, Brasília, v. 17, n. 34, jul.-dez. 2017.

STEDILE, João Pedro. O MST e a questão agrária. Estudos Avançados, São Paulo, v. 11, n. 31, set.-dez. 1997.

Questão agrária. In: CALDART, Roseli Salete; PEREIRA, Isabel Brasil; ALENTEJANO, Paulo; FRIGOTTO, Gaudêncio. Dicionário da educação do campo. São Paulo: Expressão Popular, 2012. p. 639-644.

WEISHEIMER, Nilson. A situação juvenil na agricultura familiar. Curitiba: CRV, 2019.

Desenvolvimento rural, capitalismo e agricultura familiar. Olhares Sociais, Cachoeira, v. 2, n. 1, maio 2013. Disponível em: <www3.ufrb.edu.br/olharessociais/wp-content/uploads/Desenvolvimento-rural-capitalismo-e-agricultura-familiar.pdf>. Acesso em: 3 jun. 2021.

Marx: categorias sociológicas fundamentais. In: UNIVERSIDADE LUTERANA DO BRASIL

(Org.). Sociologia clássica. Curitiba: Editora Ibpex, 2008. p. 154 -174. 